\title{
Frequenter contact met ouders bij volwassen mannen en vrouwen na echtscheiding
}

\author{
Tina Van Rossem ${ }^{1}$ (D), Maaike Jappens ${ }^{1}$ (D) Lindsay Theunis $^{1}$ (D) Jan Van Bavel $^{1,2}$ (D) \\ 1 Vrije Universiteit Brussel, ${ }^{2}$ Katholieke Universiteit Leuven
}

\begin{abstract}
Aan de hand van data van de survey 'Scheiding in Vlaanderen' onderzoeken we in dit artikel het verband tussen een echtscheiding van volwassen kinderen en de frequentie van ontmoetingen met hun ouders. Daarbij houden we zowel rekening met door de volwassen kinderen als door de ouders gerapporteerde contactfrequenties. De resultaten tonen aan dat gescheiden personen meer contact hebben met beide ouders dan gehuwden. Meer specifiek geldt dat de frequentie van ontmoetingen het hoogst is wanneer men na de echtscheiding niet samenwoont met een nieuwe partner. De verschillen naargelang de huwelijks- en partnerstatus zijn beduidend groter voor zoons dan voor dochters.
\end{abstract}

\section{INLEIDING}

De stijging van de levensverwachting zorgde er voor dat ouders en kinderen langere gedeelde levens kennen, en dat steeds meer families bestaan uit drie in leven zijnde generaties. Tegelijkertijd resulteerde een daling van het geboortecijfer in minder leden per generatie (Bengtson, 2001; Dykstra, 1997). Op die manier ontstond een demografische context waarin intergenerationele steunrelaties een grote rol kunnen spelen, zowel in alledaagse situaties als in tijden van emotionele, financiële of praktische nood (Dykstra \& Fokkema, 2011; Swartz, 2009).

Net als elders veranderden gezinnen echter ingrijpend in België (Van Peer \& Carrette, 2007). Zo daalde het aantal huwelijken, en nam het echtscheidingscijfer sterk toe. In 2008 had België zelfs het hoogste bruto echtscheidingscijfer in internationale context, na de Verenigde Staten van Amerika. In 2010 behield België een top 5 plaats, en vonden er per 1000 personen 2,67 echtscheidingen plaats in België en 2,19 in het Vlaams Gewest (Corijn, 2012). We kunnen dus stellen dat een aanzienlijk deel van de Belgische bevolking vroeg of laat geconfronteerd wordt met een echtscheiding.

Over de impact van het toegenomen aantal echtscheidingen op intergenerationele relaties bestaan algemeen genomen twee uiteenlopende verwachtingen. Een pessimistische visie stelt dat echtscheidingen niet enkel negatieve implicaties hebben voor het kerngezin van ouders en inwonende kinderen, maar ook bredere familiale netwerken ondermijnen (Popenoe, 1993; Teachman, Tedrow, \& Crowder, 2000; Terhell, Broese van Groenou, \& van 
Tilburg, 2001, 2007). Daarnaast zijn er echter ook onderzoekers die een meer optimistische visie hanteren. Zij benadrukken dat uitgebreide familierelaties, ondanks de recente veranderingen, wel nog steeds een relevante rol spelen in de huidige westerse samenlevingen (Bucx, Van Wel, Knijn, \& Hagendoorn, 2008; Swartz, 2009; Tomassini et al., 2004; Wijckmans \& Van Bavel, 2013). Door de broosheid van aangetrouwde familierelaties, zou de rol van relaties met bloedverwanten misschien zelfs nooit eerder zo groot geweest zijn (Bengtson, 2001).

Dit artikel gaat over de relatie tussen volwassen kinderen en hun ouders na echtscheiding. Verschillende studies stelden al vast dat een echtscheiding in de oudergeneratie negatieve gevolgen kan hebben voor de relatie met de kinderen op volwassen leeftijd (zie ondermeer Lye, 1996; Lye, Klepinger, Davis Hyle, \& Nelson, 1995; Swartz, 2009; Tomassini et al., 2004; Vanderleyden \& Audenaert, 2004). Wat een echtscheiding van volwassen kinderen concreet doet met hun uitgebreide familierelaties, werd tot nu toe echter weinig onderzocht, ze- ker in de Belgische context. Bovendien formuleren bestaande studies uiteenlopende conclusies (Wijckmans, Jappens, \& Van Bavel, 2011). Op basis van de survey 'Scheiding in Vlaanderen' werden recent wel enkele studies uitgevoerd over het contact tussen grootouders en kleinkinderen na echtscheiding van de ouders (zie Jappens \& Van Bavel, 2012, 2013). Daarnaast werden al beschrijvende analyses over het contact en de steunuitwisseling tussen gescheiden personen en hun vrienden en familie gepubliceerd (Jappens, Wijckmans, \& Van Bavel, 2011; Wijckmans, Jappens, \& Van Bavel, 2011). Wij bestuderen in dit artikel de impact van een echtscheiding van het volwassen kind op de frequentie van contacten met zijn of haar ouders door middel van regressie-analyses. Die contacten zijn belangrijk voor beide partijen, en zeker in de vaak moeilijke periode na een echtscheiding, wanneer extra steun op verschillende vlakken welkom is (Carrette \& Van Peer, 2007; Wijckmans, Jappens, \& Van Bavel, 2009).

\section{Over het onderzoek Scheiding in Vlaanderen (SIV)}

SiV-data zijn afkomstig van het onderzoek "Scheiding in Vlaanderen". In dit onderzoek werd via een interview informatie verzameld bij beide partners van eerste huwelijken die afgesloten zijn tussen 1971 en 2008 en intussen al dan niet ontbonden zijn. Ook een kind, een ouder en een eventuele nieuwe partner van deze personen werden indien mogelijk bevraagd. Zij kregen een schriftelijke vragenlijst of websurvey aangeboden. De gegevens zijn verzameld in de periode van september 2009 tot december 2010.
12110 van alle 26376 gecontacteerde personen konden bevraagd worden wat een totale respons van $46 \%$ oplevert voor deze multi-actorstudie over huwelijk en echtscheiding. Gedetailleerde informatie over dit onderzoek en deze dataverzameling vindt $u$ op www.scheidinginvlaanderen.be en in het boek: Mortelmans Dimitri, Pasteels Inge, Bracke Piet, Matthijs Koen, Van Bavel Jan, Van Peer Christine (2011) Scheiding in Vlaanderen. ISBN 978-90-334-85862 - Leuven: Acco, 355 p. 
We onderzoeken het verband tussen een echtscheiding van volwassen kinderen en contacten met hun ouders op basis van data van de survey 'Scheiding in Vlaanderen' (SiV). We concentreren ons op de frequentie van ontmoetingen tussen ouder en kind, omdat dit een vorm van contact is die zich het best leent tot de uitwisseling van steun. Zien gescheiden volwassen kinderen hun ouders vaker dan gehuwden? Is dit het geval voor mannen én vrouwen? Speelt de aanwezigheid van kleinkinderen een rol? En wat als er na de echtscheiding een nieuwe partner komt? Om deze vragen te kunnen beantwoorden maken we dankbaar gebruik van het multi-actor design van de SiV-studie: we baseren ons zowel op informatie die we verkregen bij de volwassen kinderen als op informatie die we verzamelden bij hun ouders.

In de volgende paragraaf geven we een kort overzicht van de literatuur over echtscheiding en contact tussen volwassen kinderen en hun ouders. Daarna gaan we dieper in op de data en de onderzoeksmethode die we gebruiken. In de vijfde paragraaf bespreken we de resultaten van de statistische analyses. Tot slot trekken we conclusies.

\section{LiteratuUR}

\subsection{ECHTSCHEIDING VAN HET VOLWASSEN KIND}

Sommige onderzoekers stelden vast dat een echtscheiding van een volwassen kind gemiddeld tot een minder frequent contact met de ouders leidde (Hagestad, 1986; Kaufman \& Uhlenberg, 1998). Als verklaring worden ondermeer toegenomen conflicten en stress tussen scheidende kinderen en hun ouders aangehaald. Volwassen kinderen steunen namelijk vaak noodgedwongen op hun ouders voor emotionele en financiële steun wanneer ze door een echtscheiding gaan, een situatie die niet altijd positief ervaren wordt door beide partijen. Bovendien kunnen scheidende kinderen op hun beurt vaak minder steun verlenen aan hun ouders omdat ze druk bezig zijn met het herordenen van hun eigen leven (Dykstra, 1997; Kaufman \& Uhlenberg, 1998; Lye, 1996; Rands, 1988; Virpi, Doyle, \& O’Dwyer, 2011).

Andere studies concludeerden daarentegen dat er weinig verschillen bestaan qua contact tussen ouders en hun volwassen kinderen naargelang de kinderen al dan niet gescheiden zijn (Kalmijn \& Broese van Groenou, 2005; Lawton, Silverstein, \& Bengtson, 1994; Rossi \& Rossi, 1990). Sommige auteurs vinden zelfs een patroon van toegenomen contact met bloedverwanten terug na echtscheiding (Johnson, 1988; Spitze, Logan, Deane, \& Zerger, 1994). Dit zou volgens hen te maken hebben met het gegeven dat eigen familieleden meestal zwak verbonden zijn met de ex-partner, en ze niet ongevoelig zullen zijn voor de noodzaak aan hulp die ontstaat na de echtscheiding (Kalmijn \& Broese van Groenou, 2005). De evolutie naar een grotere tolerantie ten aanzien van echtscheidingen (Inglehart, 2008) belemmert het contact trouwens niet langer (of in veel mindere mate). Een minder frequent contact tussen gehuwde personen en hun ouders wordt tenslotte ook gelinkt aan het gegeven dat gehuwden hun gelimiteerde tijd over een groter netwerk van sociale actoren dienen te verdelen. Bij gespannen verhoudingen tussen schoonkinderen en schoonouders gaan sommige gehuwden contact mogelijk uit de weg (Bucx et al., 2008). 


\subsection{DETERMINANTEN VOOR DE CONTACT- FREQUENTIE TUSSEN VOLWASSEN KIND- EREN EN HUN OUDERS}

In het contact tussen ouders en volwassen kinderen na echtscheiding spelen verscheidene factoren een rol.

In eerste instantie is er het geslacht van het volwassen kind: vrouwen ontmoeten hun ouders beduidend meer dan mannen (Bucx et al., 2008; Jappens et al., 2011; Lye et al., 1995; Spitze et al., 1994; Vanderleyden \& Audenaert, 2004; Wijckmans et al., 2009). Vrouwen zijn met andere woorden de kinkeepers: zij onderhouden de familiebanden, terwijl eventuele echtgenoten meeliften met de sociale contacten van hun vrouw (De Koker, 2007; Jappens et al., 2011; Terhell et al., 2001). Bijgevolg onderhouden mannen tijdens het huwelijk minder contact met hun ouders dan voor het huwelijk, omdat de echtgenotes die rol grotendeels op zich nemen (Sarkisian \& Gerstel, 2008). Na de echtscheiding dienen ze vervolgens opnieuw zelf in te staan voor het onderhouden van de familiebanden.

Ten tweede dient er te worden nagegaan of de gescheiden volwassenen zelf reeds moeder of vader zijn. De frequentie van contact met de ouders kan dan namelijk afnemen, omdat de volwassen kinderen tijd en energie aan hun eigen nageslacht besteden (Rossi \& Rossi, 1990). Anderzijds kan er net sprake zijn van een toegenomen contact met de ouders, omdat die bijvoorbeeld helpen met zorg en kinderopvang (Bucx et al., 2008; Cooney \& Uhlenberg, 1992; Spitze et al., 1994).

Vermits veel gescheiden personen na verloop van tijd hertrouwen of een nieuwe samenwoonrelatie aangaan (Corijn, 2013; Pasteels \& Mortelmans, 2013; Rands, 1988; Terhell et al., 2001), is het tevens belangrijk om hun huidig partnerstatuut in rekening te brengen. Gescheiden kinderen die een nieuwe partner hebben, geven namelijk minder vaak aan een zeer sterke band met hun ouders te hebben dan diegenen die na echtscheiding nog alleenstaand zijn (Johnson, 1988). Alleenstaande gescheiden volwassenen zouden dus meer contact met hun ouders onderhouden dan gehuwden of dan gescheiden personen met een nieuwe partner. Dit geldt in de eerste plaats voor vrouwen, terwijl de bevindingen in andere studies iets minder eenduidig zijn voor mannen (Kalmijn \& Broese van Groenou, 2005; Wijckmans et al., 2009).

Ook de leeftijd speelt een rol, in eerste instantie die van de volwassen kinderen. In de literatuur terzake bestaat er echter discussie of de band tussen ouders en kinderen het sterkst is bij jongvolwassenen (Rossi \& Rossi, 1990; Swartz, 2009), of eerder toeneemt naarmate de volwassen kinderen ouder zijn (Kaufman \& Uhlenberg, 1998; Lawton et al., 1994). Ook de beschikbare tijd van de volwassen kinderen is belangrijk. Meer werkuren laten namelijk minder tijd over voor contact (Lye, 1996; Rossi \& Rossi, 1990; Wijckmans et al., 2009). De impact van het opleidingsniveau en inkomen is niet helemaal duidelijk (Lawton et al., 1994; Sarkisian \& Gerstel, 2008). Meestal leidt het feit dat hoger geschoolden vaak verder weg wonen van hun ouders dan lager geschoolden indirect tot een lagere contactfrequentie (Kalmijn, 2006; Lawton et al., 1994; Michielin \& Mulder, 2007). Geografische nabijheid is namelijk sterk geassocieerd met een hogere frequentie van intergenerationeel contact (Bengtson \& Roberts, 1991; Bucx et al., 2008; Kaufman \& Uhlenberg, 1998; Michielin \& Mulder, 2007; Vanderleyden \& Audenaert, 2004).

Naast de vermelde eigenschappen van de volwassen kinderen, zijn ook enkele kenmerken van de ouders van belang bij het onderhouden 
van contact. Ten eerste is dat hun burgerlijke staat. Weduwen en weduwnaars hebben in bepaalde gevallen een betere band met hun kinderen dan getrouwde en gescheiden ouders (Lawton et al., 1994; Tomassini et al., 2004). En in vergelijking met volwassen kinderen wiens ouders gehuwd zijn, bezoeken volwassen kinderen van gescheiden ouders hen minder (Lye, 1996; Lye et al., 1995; Swartz, 2009; Tomassini et al., 2004; Vanderleyden \& Audenaert, 2004). De echtscheiding van de ouders heeft dus mogelijk een negatief effect op de relatie tussen ouders en hun (volwassen) kinderen. Het geslacht van de ouders is eveneens van fundamenteel belang. Moeders zijn over het algemeen sterker verbonden met hun kinderen dan vaders (Kaufman \& Uhlenberg, 1998; Lawton et al., 1994; Lye et al., 1995; Spitze et al., 1994; Swartz, 2009). Na echtscheiding geldt dit patroon nog meer: voornamelijk gescheiden vaders zijn geïsoleerd van hun volwassen kinderen (Dykstra, 1997; Lawton et al., 1994; Lye, 1996; Tomassini et al., 2004). Daarnaast is tevens de leeftijd van de ouders van belang. Enerzijds nemen sociale contacten af naargelang personen ouder worden (Vanderleyden \& Audenaert, 2004). Anderzijds kan de toenemende nood aan hulp op oudere leeftijd, vaak ten gevolge van een slechtere gezondheid, voor meer frequent bezoek van de volwassen kinderen zorgen (Tomassini et al., 2004). Tenslotte brengen we ook het opleidingsniveau en de sociale klasse van de ouders in rekening, en het aantal kinderen dat ze hebben. Ouders met meer kinderen kunnen namelijk minder tijd besteden aan elk kind afzonderlijk (Kalmijn \& Dykstra, 2006; Lye, 1996; Rossi \& Rossi, 1990). De volwassen kinderen stemmen hun eigen gedrag ook af op dat van hun broers of zussen (Dykstra \& Fokkema, 2011).

\section{DAta}

In dit onderzoek wordt gebruikgemaakt van de ongewogen data van het surveyonderzoek 'Scheiding in Vlaanderen'. De bedoeling van deze survey is om meer te weten te komen over de oorzaken en gevolgen van echtscheidingen in Vlaanderen. Bijgevolg is er gezorgd voor een oververtegenwoordiging van gescheiden personen in de uiteindelijke databank: meer dan twee derde van de bevraagde partners is gescheiden (Pasteels, Mortelmans \& Van Bavel, 2011). Daarnaast geldt dat deze survey is opgesteld als een multi-actordesign: de bevraging van de (ex-)partners én hun ouders is voor ons onderzoek zeer belangrijk. We gebruiken namelijk data van beide actoren om onze onderzoeksvraag te beantwoorden. Gelet op de hypothese van het intergenerationeel belang ("the intergenerational stake hypothesis") is dit niet onbelangrijk. Deze hypothese stelt dat de oudere generatie meestal meer belang hecht aan een goede relatie met de jongere generatie en daarom in surveys ook een betere relatie met de jongere generatie rapporteert dan omgekeerd (Bengtson, 2001; Swartz, 2009). Indien de resultaten in dezelfde richting wijzen, geeft deze dubbele onderzoeksmethode bijgevolg extra kracht aan de conclusies van dit onderzoek. Daarnaast biedt het de mogelijkheid om te controleren voor extra variabelen die enkel via de ouders werden bevraagd.

De op de bevraging van de ouders gebaseerde dataset is gekoppeld aan de informatie die door de (ex-)partners is gerapporteerd. Wanneer we doelen op de generatie van de al dan niet gescheiden (ex-)partners, spreken we consequent over volwassen kinderen. Met de termen ouder, moeder of vader verwijzen we naar hun ouders. De kinderen van het volwassen kind, oftewel de kleinkinderen, maken een derde generatie uit. 
Omdat samenwonen met één ouder of met beide ouders een speciale situatie vormt (zie ondermeer Lye, 1996; Wijckmans \& Van Bavel, 2013), opteren wij er in dit onderzoek voor om deze respondenten uit de analyses te weren. lemand die enkel samenwoont met zijn of haar moeder is dus bijvoorbeeld ook niet opgenomen in de analyses van het contact met de nog levende vader. Dit criterium sluit slechts een tiental personen uit de analyses. Uiteraard vallen in de analyses ook die personen weg wiens respectievelijke ouder niet meer leeft. Bij 1693 van de 6366 ondervraagde volwassen kinderen is de moeder niet meer in leven, en bij 2856 ondervraagde personen is hun vader overleden. Tenslotte worden er nog respondenten geweerd omwille van ontbrekende of foutieve antwoorden voor ingebrachte variabelen. $\mathrm{Na}$ deze selecties kunnen we voor 4321 respondenten hun rapportering over contact met de moeder analyseren. Van deze respondenten zijn er 1190 nog steeds gehuwd en 3131 gescheiden. Voor de analyses omtrent contact met de vader blijven 3215 respondenten beschikbaar, waarvan 931 met een intact en 2284 met een ontbonden huwelijk. Op dezelfde manier kunnen voor de analyses op basis van de dataset van de ouders 1667 ouder-kind koppels worden geselecteerd. In 574 gevallen is het bestudeerde huwelijk van het volwassen kind nog steeds intact, terwijl bij de andere 1093 dyades het huwelijk van het volwassen kind is ontbonden.

Omdat banden tussen ouders en volwassen kinderen niet enkel via ontmoetingen onderhouden kunnen worden, peilt de SiV-vragenlijst ook naar contact via telefoon, post en email. Dit artikel beperkt zich echter tot contact via face-to-face ontmoetingen. Uit onderzoek van Van Rossem (2013) blijkt immers dat de resultaten voor andere vormen van contact zeer gelijklopend zijn.

\section{Methoden}

We starten met enkele beschrijvende figuren, gevolgd door meervoudige regressie-analyses. Die analyses voeren we eerst uit op de dataset van de volwassen kinderen en daarna op de gekoppelde dataset van de ouders. De afhankelijke variabele betreft het aantal gerapporteerde ontmoetingen per jaar. Voor een overzicht van de bevraging en de constructie van deze en de andere gebruikte variabelen verwijzen we naar de bijlage. De belangrijkste beschrijvende kenmerken van de variabelen worden er eveneens weergegeven.

De modellen met betrekking tot de dataset van de volwassen kinderen zijn opgesplitst naargelang het gaat om contact met de moeder of met de vader van de respondent. Voor beide ouders worden vier identieke modellen gepresenteerd. Het eerste model focust op het verschil tussen gescheiden en gehuwde volwassen kinderen. Het tweede model verschilt van het eerste door de opname van interactietermen tussen huwelijksstatus en geslacht en tussen huwelijksstatus en de aanwezigheid van kleinkinderen. Dit om te testen of het effect van huwelijksstatus varieert naargelang het geslacht van het volwassen kind en naargelang de aanwezigheid van kleinkinderen. Afgaand op de besproken literatuur kunnen we dit inderdaad verwachten. Vanaf het derde model interesseren we ons niet louter in het verschil tussen gehuwde en gescheiden personen, maar houden we eveneens rekening met de aan- of afwezigheid van een nieuwe partner in het huishouden van gescheiden personen. In het vierde model wordt tenslotte een interactieterm ingebracht tussen partnerstatuut en geslacht, naar analogie met de interactieterm tussen huwelijksstatus en geslacht. In al deze analyses vormen de personen met een intact huwelijk de referentiegroep, tenzij anders vermeld. De analyses op de door de ouders gerapporteerde frequentie 
van contact volgen dezelfde opbouw. Belangrijk is wel dat er een aantal extra variabelen worden ingebracht, en dat contacten gerapporteerd door moeders en vaders samen in een model geanalyseerd worden. Dit maakt het immers mogelijk om na te gaan of moeders significant meer contact rapporteren dan vaders, zoals we kunnen verwachten op basis van de literatuur.

\section{Resultaten}

\subsection{BESCHRIJVENDE ANALYSES}

In de eerste plaats geven we een grafisch overzicht van het aantal ontmoetingen per jaar met de ouders naargelang het huidig partnerstatuut en geslacht van het volwassen kind. De frequentie van de ontmoetingen tussen volwassen kinderen en hun moeder wordt weergegeven in figuur 1 , de frequentie van de ontmoetingen met de vader wordt weergegeven in figuur 2. We kunnen eruit afleiden dat volwassen kinderen hun ouders globaal gezien regelmatig ontmoeten. Slechts een kleine minderheid heeft helemaal geen contact. De verschillen naargelang geslacht vallen meteen op: vaders ontmoeten hun volwassen kinderen minder frequent dan moeders, en dochters onderhouden de contacten met hun ouders op een meer regelmatige basis dan zoons.

Als we vervolgens de bevindingen interpreteren naargelang het huidig partnerstatuut van het volwassen kind, blijkt dat mannen die gescheiden zijn en niet samenwonen met een nieuwe partner vaker op regelmatige basis contact hebben met hun ouders dan diegenen die gehuwd zijn of na echtscheiding samenleven met een partner. Voor vrouwen geldt dit niet zo sterk en zijn de verschillen niet significant. We zien verder ook dat, in vergelijking met gehuwden, een groter aandeel gescheiden vrouwen en mannen totaal geen contact heeft met de ouders. Het is echter belangrijk om aan te stippen dat deze analyses enkel betrekking hebben op de personen die niet samenwonen met hun ouders. Vermits een beduidend groter aandeel gescheiden dan gehuwde personen samenwoont met hun ouders, dient deze bevinding dus genuanceerd te worden. Van de gescheiden respondenten zijn het voornamelijk de alleenstaande mannen (bijna 9\%) die samenwonen met hun ouders (Jappens et al., 2011). 
Figuur 1 Percentage volwassen kinderen dat hun moeder minstens één keer per week, per maand, per jaar of nooit ontmoet; naar huidig partnerstatuut en geslacht

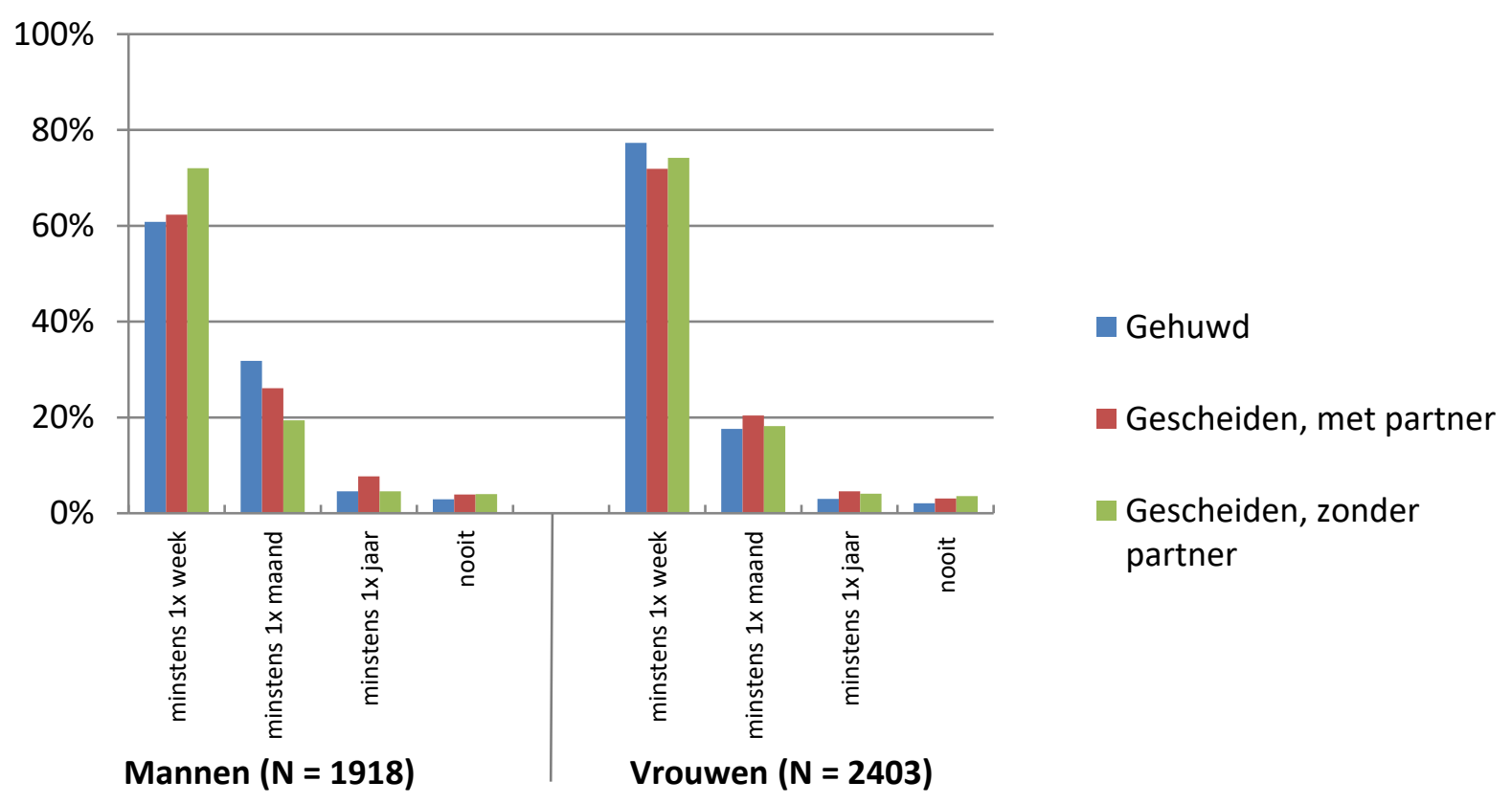

Bron: Scheiding in Vlaanderen, 2009-2010

Figuur 2 Percentage volwassen kinderen dat hun vader minstens één keer per week, per maand, per jaar of nooit ontmoet; naar huidig partnerstatuut en geslacht

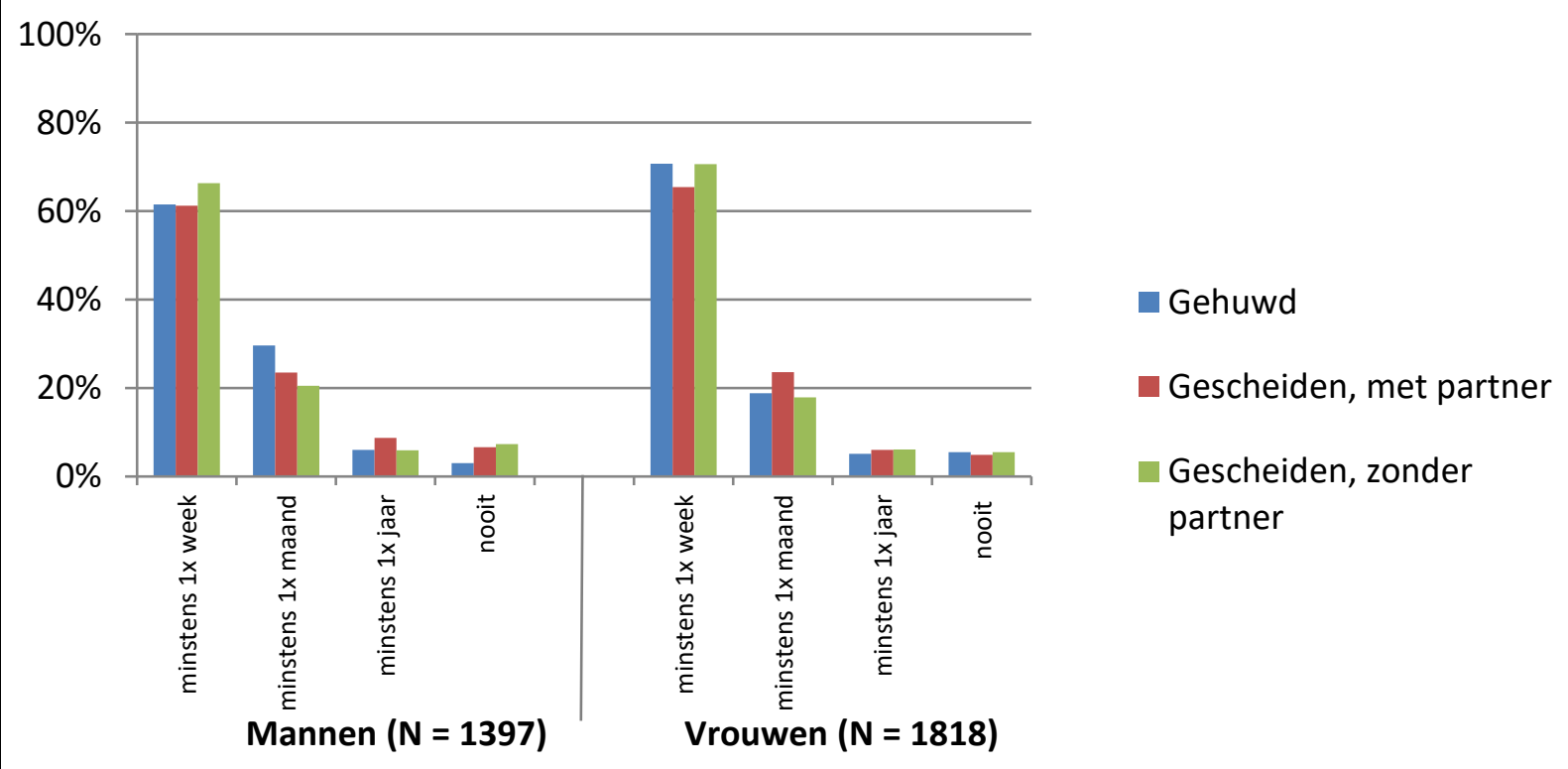

Bron: Scheiding in Vlaanderen, 2009-2010 


\subsection{MULTIVARIATE ANALYSES}

In tabel 2 en 3 worden de resultaten van de lineaire regressiemodellen van het aantal jaarlijkse ontmoetingen tussen de volwassen kinderen en hun ouders weergegeven. Tabel 2 werd opgesteld met behulp van de databank van de volwassen kinderen, tabel 3 is gebaseerd op de door de ouders gerapporteerde contactfrequentie. We bespreken telkens eerst de bevindingen op basis van de volwassen kinddata, vervolgens geven we aan of er een verschil optreedt indien we naar de rapportering van de ouders kijken.

Uit model 1 kunnen we afleiden dat gescheiden personen hun moeder en vader significant meer ontmoeten dan gehuwde zoons en dochters. Vrouwen onderhouden in beide gevallen eveneens significant meer contact dan mannen, en de aanwezigheid van kleinkinderen stimuleert de ontmoetingen evenzeer. Wat de controlevariabelen betreft, zien we meestal de verbanden die we verwachtten. Er vinden immers minder ontmoetingen met de ouders plaats naarmate het volwassen kind ouder is, meer werkuren klopt, hooggeschoold is, verder weg woont en meer broers of zussen heeft. Als de ouders gescheiden zijn, hebben volwassen kinderen minder contact met hen, vooral met gescheiden vaders. Ontmoetingen worden daarentegen gestimuleerd door een hogere leeftijd van de ouders. En in vergelijking met gehuwde moeders, is er meer contact wanneer de moeder verweduwd is.

Op basis van de rapportering door de ouders stellen we vast dat moeders hun volwassen kinderen inderdaad meer ontmoeten dan vaders. De meeste andere verbanden in dit model wijzen overigens in dezelfde richting als in het model op basis van de rapportering van de volwassen kinderen. Wat betreft de extra opgenomen controlevariabelen, suggereren de resultaten dat ouders met een betaalde job hun volwassen kinderen minder ontmoeten dan ouders zonder een betaalde job, net als midden- en hooggeschoolde ouders in vergelijking met laaggeschoolden, en ouders met een goede gezondheid in vergelijking met diegenen met een slechte tot redelijke gezondheidstoestand.

Model 2 verschilt van het voorgaande door de opname van verschillende interactietermen. Uit de interactieterm tussen de huwelijksstatus en het geslacht van het volwassen kind kunnen we afleiden dat de huwelijksstatus voornamelijk voor mannen van belang is voor het onderhouden van contact met de ouders. Gescheiden mannen zullen hun ouders naar verwachting veel meer ontmoeten dan gehuwde mannen, terwijl het verschil in ontmoetingen tussen gescheiden en gehuwde vrouwen beduidend kleiner is. Dit geldt voor contact met beide ouders, maar de term is niet significant voor contact met de vader. We kunnen deze bevinding linken aan de kinkeeper-rol van vrouwen tijdens het huwelijk, waardoor mannen na de echtscheiding zelf terug de contacten met hun ouders dienen te onderhouden.

Een tweede interactieterm is deze tussen de huwelijksstatus en de aanwezigheid van kleinkinderen. De richting van het verband suggereert dat de positieve invloed van kleinkinderen minder sterk is voor gescheiden respondenten dan voor gehuwden, maar deze term is statistisch niet significant. De derde en laatste interactieterm is deze tussen het geslacht van het volwassen kind en de aanwezigheid van kleinkinderen. Het effect is telkens positief, maar de benodigde significantie wordt enkel bereikt indien we de frequentie van ontmoetingen met de moeder als afhankelijke variabele nemen. Dit zal waarschijnlijk te maken hebben met het gegeven dat voornamelijk moeders hun volwassen kinderen bijstaan in de 
zorg voor de jongste generatie. De interactieterm toont aan dat het contact tussen dochters en hun moeder meer wordt gestimuleerd door de aanwezigheid van kleinkinderen dan het contact met zoons. Dit verband wijzigt niet wanneer alleen rekening wordt gehouden met de gescheiden respondenten (resultaten niet in tabel).

Wanneer er zorg dient gedragen te worden voor kleinkinderen, hebben gescheiden zoons dus minder contact met hun moeder dan gescheiden dochters. De variabele differentieert echter niet naar de verblijfsstatus van de kleinkinderen, en er wordt eveneens geen onderscheid gemaakt tussen biologische kinderen en stiefkinderen. Deze meting kan de resultaten verklaren. Aangezien het gros van de Vlaamse kinderen nog steeds bij de moeder woont na een echtscheiding (Sodermans, Vanassche, \& Matthijs, 2011), zullen de door de volwassen mannen opgegeven inwonende kinderen waarschijnlijk vaak slechts voor korte tijd bij hen verblijven. Bovendien zal het ook vaak stiefkinderen betreffen. De analyses met betrekking tot de door de ouders gerapporteerde data bevestigen al deze bevindingen.

Uit model 3 blijkt dat herpartneren na echtscheiding een belangrijke rol speelt. Alleenstaande gescheiden personen ontmoeten hun ouders significant meer dan gehuwden. Het verschil tussen gescheiden personen met een nieuwe partner en gehuwden is daarentegen veel kleiner en statistisch niet significant. Niet weergegeven analyses bij de groep van gescheidenen bevestigen overigens dat alleenstaande gescheiden personen hun beide ouders significant meer ontmoeten dan diegenen met een nieuwe samenwoonrelatie. Gehuwden en gescheiden personen met een nieuwe partner gelijken dus het meest op elkaar wat betreft het onderhouden van contact met de ouders. Dit suggereert dat de uitbreiding van iemands netwerk bij een eerste huwelijk én bij herpartneren na echtscheiding ongeveer dezelfde uitwerking heeft op het aantal ontmoetingen met de ouders. Model 4 toont bovendien aan dat het effect van herpartneren op ontmoetingen met de moeder groter is voor mannen dan voor vrouwen: het zijn voornamelijk de alleenstaande gescheiden mannen die hun moeder vaker ontmoeten. Analyse van de informatie vergaard bij de ouders leidt tot dezelfde conclusies. 


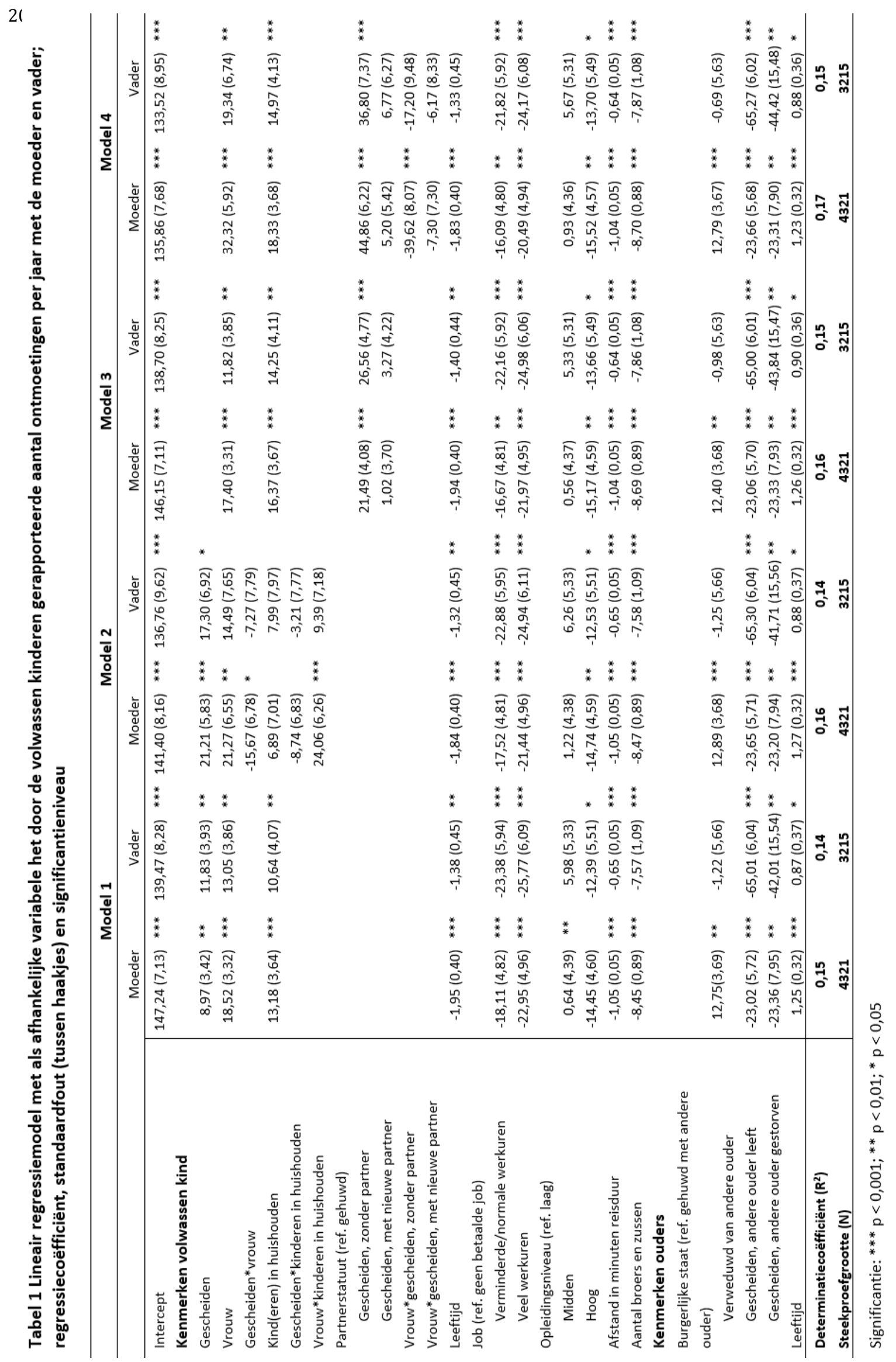









\section{Conclusie}

In het onderzoek rond echtscheiding worden vaak eenzijdig de negatieve implicaties voor hedendaagse familiebanden belicht. Wat soms uit het oog verloren wordt, is dat net in tijden van hoge echtscheidingscijfers, intergenerationele familierelaties een belangrijke rol kunnen vervullen. Intergenerationele familiebanden zijn in crisisperiodes misschien zelfs belangrijker dan ooit. Empirisch onderzoek omtrent deze kwestie is echter beperkt, zeker voor België en Vlaanderen. Dit onderzoek probeerde alvast meer wetenschappelijke kennis te verkrijgen omtrent echtscheiding en de relatie tussen ouders en hun volwassen kinderen. We bestudeerden meer bepaald de verschillen tussen gehuwde en gescheiden Vlamingen betreffende ontmoetingen met hun ouders. Daarvoor gebruikten we de data van het grootschalige scheidingsonderzoek 'Scheiding in Vlaanderen'.

Een bijzondere meerwaarde van dit onderzoek is dat we gebruik hebben gemaakt van de door de survey geboden mogelijkheid om zowel met het perspectief van de volwassen kinderen als met het perspectief van de ouders rekening te houden. Dat de resultaten op basis van de twee perspectieven nauwelijks verschillen wat betreft de richting van de verbanden, versterkt de betrouwbaarheid van onze bevindingen.

De analyses wijzen er ondubbelzinnig op dat de frequentie van contact met de ouders verschilt naargelang de huwelijksstatus van het volwassen kind: gescheiden personen, en vooral gescheiden mannen, ontmoeten hun ouders méér dan gehuwden. We kunnen veronderstellen dat dit veroorzaakt wordt door de grotere noodzaak aan hulp na echtscheiding. De ouders zullen bijgevolg veel steun verschaffen. Daarnaast geldt dat volwassen kinderen na echtscheiding ook meer tijd hebben om de contacten met hun ouders te onderhouden. $\mathrm{Er}$ is immers een deel van hun sociale netwerk, met name de schoonfamilie, weggevallen. Verder blijkt dat kleinkinderen het contact tussen volwassen kinderen en hun ouders over het algemeen stimuleren, voornamelijk tussen moeders en dochters. Dit kan wellicht verklaard worden door de verblijfsregeling van de kinderen: ondanks de opkomst van het verblijfscoouderschap, staan vrouwen nog steeds het meest in voor de zorg van de kinderen. Daarbij krijgen ze wellicht ze hulp van hun eigen moeder.

Niet alleen een echtscheiding van volwassen kinderen op zich, maar ook het eventuele herpartneren nadien blijkt van belang voor de frequentie van ontmoetingen met ouders. Gescheiden mannen en vrouwen die niet samenleven met een partner ontmoeten hun ouders meer dan gehuwden, en eveneens meer dan gescheiden personen met een nieuwe samenwoonrelatie. Ook dit geldt het meest voor mannen. We hebben geen informatie over de inhoud van ontmoetingen, maar onze resultaten doen vermoeden dat meer contact ook betekent dat ouders extra steun verlenen aan hun alleenstaande gescheiden kinderen, zij het praktisch of emotioneel. De resultaten tonen eveneens aan dat personen nood hebben aan vertrouwenscontacten. Wanneer ze niet kunnen terugvallen op een partner, wenden ze zich vaker tot (één van) hun ouders. Slechts een kleine proportie zoons en dochters geeft aan hun ouders nooit te ontmoeten. De partnerstatus van de volwassen kinderen speelt hierbij geen belangrijke rol.

Onze bevindingen gaan dus in tegen het idee van verstoorde familierelaties na echtscheiding. De echtscheiding van een zoon heeft over 
het algemeen een positief effect op de contacten met de ouders, en in mindere mate geldt dit ook voor de echtscheiding van een dochter - al is er voor hen dan weer meer contact als ze kinderen hebben. Ander onderzoek kwam tot de conclusie dat de echtscheiding van de ouders vaak leidt tot verminderde contacten met hun volwassen kinderen, iets wat we ook in onze analyses vaststelden. De echtscheiding van de volwassen kinderen blijkt daarentegen meestal niet te leiden tot een daling van het ouder-kind contact in hedendaags Vlaanderen. Integendeel.

Dit onderzoek en de gebruikte database hebben ook enkele beperkingen. In de eerste plaats beschikken we enkel over gegevens verzameld op één tijdstip. We kunnen daarmee wel gehuwde en gescheiden respondenten vergelijken maar dat laat strikt genomen geen uitspraken over causaliteit toe. Het is immers mogelijk dat personen die gescheiden zijn en meer contact rapporteren met hun ouders, reeds meer contact onderhielden vooraleer ze gescheiden zijn. Dergelijke verschillende sociale relaties kunnen zelfs bijgedragen hebben aan de latere echtscheiding. Een retrospectieve bevraging of een longitudinaal onderzoek kan een oplossing bieden voor dit probleem. Daarnaast geldt dat de selectie van de ouders hoogstwaarschijnlijk voor een vertekening zorgt. Diegenen die niet langer contact hebben met hun volwassen kinderen of diegenen die een slechte relatie met hen ervaren, zijn ten gevolge van de opzet van het multi-actor design sterk ondervertegenwoordigd. En er geldt eveneens dat, in vergelijking met ouders van gescheiden respondenten, een groter aandeel ouders van gehuwde partners heeft meegewerkt (Pasteels, Mortelmans, \& Van Bavel, 2011). Een bijkomend nadeel is dat de dataset geen mogelijkheid biedt om een vergelijking te maken met nooit gehuwden en met personen die reeds meerdere keren gescheiden zijn. 


\section{REFERENTIES}

Bengtson, V. L. (2001). Beyond the nuclear family: the increasing importance of multigenerational bonds. Journal of Marriage and Family, 63(1), 1-16. doi: 10.1111/j.1741-3737.2001.00001.x

Bengtson, V. L., \& Roberts, R. E. L. (1991). Intergenerational solidarity in aging families: an example of formal theory construction. Journal of Marriage and the Family, 53(4), 856-870.

Bucx, F., Van Wel, F., Knijn, T., \& Hagendoorn, L. (2008). Intergenerational contact and the life course status of young adult children. Journal of Marriage and Family, 70(1), 144-156. doi: 10.1111/j.17413737.2007.00467.x

Carrette, V., \& Van Peer, C. (2007). De impact van een scheiding op kinderen en ex-partners: lessen uit het scheidingsonderzoek. In C. Van Peer (Ed.), De impact van een (echt)scheiding op kinderen en ex-partners (pp. 230-264). Brussel: Studiedienst van de Vlaamse Regering.

Cooney, T. M. \&, Uhlenberg, P. (1992). Support from parents over the life course: the adult child's perspective. Social Forces, 71(1), 63-84. doi: 10.1093/sf/71.1.63

Corijn, M. (2012). Sluiting en ontbinding van een eerste, tweede en derde huwelijk in het
Vlaamse Gewest (1970-2010). Een analyse op basis van Rijksregistergegevens. Brussel: Studiedienst van de Vlaamse Regering, SVR-webartikel 1.

Corijn, M. (2013). Ongehuwd samenwonen na een echtscheiding in Vlaanderen. Brussel: Studiedienst van de Vlaamse Regering, SVR-webartikel 3.

De Koker, B. (2007). Impact op de sociale relaties van ex-partners. In C. Van Peer (Ed.), De impact van een (echt)scheiding op kinderen en ex-partners (pp. 188-203). Brussel: Studiedienst van de Vlaamse Regering.

Dykstra, P. A. (1997). The effects of divorce on intergenerational exchanges in families. The Netherlands Journal of Social Sciences, 33(2), 77-93.

Dykstra, P. A., \& Fokkema, T. (2011). Relationships between parents and their adult children: a West-European typology of late-life families. Ageing and Society, 31(4), 545-569. doi: $10.1017 /$ S0144686X10001108

FOD Werkgelegenheid, Arbeid en Sociaal Overleg (2013). Arbeidsreglementering: arbeidsduur en rusttijden. Brussel: Belgische Federale Overheidsdiensten. Retrieved from http://www.werk.belgie.be/defaultTab.aspx?id=388 
Inglehart, R. (2008). Changing values among western publics from 1970 to 2006 . WestEuropean Politics, 31(1-2), 130-146. doi: $10.1080 / 01402380701834747$

Jappens, M., Wijckmans, B., \& Van Bavel, J. (2011). Contact en relaties met vrienden en familie. In D. Mortelmans, I. Pasteels, P. Bracke, K. Matthijs, J. Van Bavel, \& C. Van Peer (Eds.), Scheiding in Vlaanderen (pp. 283-304). Leuven: Acco.

Jappens, M., \& Van Bavel, J. (2012). Echtscheiding en contacten tussen kleinkinderen en grootouders. Tijdschrift voor Sociologie, 33(3-4), 296-328.

Jappens, M., \& Van Bavel, J. (2013). Grootouders én kleinkinderen over contact na echtscheiding. Relaties en Nieuwe Gezinnen, $3(7), 1-24$.

Johnson, C. L. (1988). Postdivorce reorganization of relationships between divorcing children and their parents. Journal of Marriage and the Family, 50(1), 221-231.

Kalmijn, M. (2006). Educational inequality and family relationships: influences on contact and proximity. European Sociological Review, 22(1), 1-16. doi: 10.1093/esr/jci036

Kalmijn, M., \& Broese van Groenou, M. I. (2005). Differential effects of divorce on social integration. Journal of Social and Personal
Relationships, 22(4), 455-476. doi: $10.1177 / 0265407505054516$

Kalmijn, M., \& Dykstra, P. A. (2006). Differentials in face-to-face contact between parents and their grown-up children. In P. A. Dykstra, M. Kalmijn, G. C. M. Knijn, A. E. Komter, A. C. Liefbroer, \& C. H. Mulder (Eds.), Family Solidarity in The Netherlands (pp. 63-87). Amsterdam: Dutch University Press.

Kaufman, G., \& Uhlenberg, P. (1998). Effects of life course transitions on the quality of relationships between adult children and their parents. Journal of Marriage and the Family, 60(4), 924-938.

Lawton, L., Silverstein M., \& Bengtson, V. (1994). Affection, social contact, and geographic distance between adult children and their parents. Journal of Marriage and the Family, 56(1), 57-68.

Lye, D. N. (1996). Adult-child parent relationships. Annual Review of Sociology, 22, 79102.

Lye, D. N., Klepinger, D. H., Davis Hyle, P., \& Nelson, A. (1995). Childhood living arrangements and adult children's relations with their parents. Demography, 32(2), 261280. doi: $10.2307 / 2061744$

Michielin, F., \& Mulder, C. H. (2007). Geographical distances between adult children and 
their parents in the Netherlands. Demographic Research, 17(22), 655-678. doi: 10.4054/DemRes.2007.17.22

Pasteels, I., \& Mortelmans, D. (2013). Gescheiden en dan? Herpartneren anno 2010. In I. Pasteels, D. Mortelmans, P. Bracke, K. Matthijs, J. Van Bavel, \& C. Van Peer (Eds.), Scheiden in meervoud. Over partners, kinderen en grootouders (pp. 2990). Leuven: Acco.

Pasteels, I., Mortelmans, D., \& Van Bavel, J. (2011). Steekproef en dataverzameling. In D. Mortelmans, I. Pasteels, P. Bracke, K. Matthijs, J. Van Bavel, \& C. Van Peer (Eds.), Scheiding in Vlaanderen (pp. 2764). Leuven: Acco.

Popenoe, D. (1993). American family decline, 1960-1990: a review and appraisal. Journal of Marriage and the Family, 55(3), 527-542.

Rands, M. (1988). Changes in social networks following marital separation and divorce. In R. M. Milardo (Ed.), Families and Social Networks (pp. 127-146). California: Sage.

Rossi, A., \& Rossi, P. (1990). Of human bonding. Parent-child relationships across the life course. New York: De Gruyter.

Sarkisian, N., \& Gerstel, N. (2008). Till marriage do us part: adult children's relationships with their parents. Journal of Marriage and Family, 70(2), 360-376. doi: 10.1111/j.1741-3737.2008.00487.x

Silverstein, M., \& Bengtson, V. L. (1997). Intergenerational solidarity and the structure of adult child parent relationships in American families. American Journal of Sociology, 103(2), 429-460.

Sodermans, A. K., Vanassche, S., \& Matthijs, K. (2011). Gezinsrelaties na ouderlijke scheiding: ouders, kinderen en nieuwe partners. In D. Mortelmans, I. Pasteels, P. Bracke, K. Matthijs, J. Van Bavel, \& C. Van Peer (Eds.), Scheiding in Vlaanderen (pp. 153-168). Leuven: Garant.

Spitze, G., Logan, J. R., Deane, G., \& Zerger, S. (1994). Adult children's divorce and intergenerational relationships. Journal of Marriage and the Family, 56(2), 279-293.

Swartz, T. T. (2009). Intergenerational family relations in adulthood: patterns, variations, and implications in the contemporary United States. Annual Review of Sociology, 35, 191-212. doi: 10.1146/annurev.soc.34.040507.134615

Teachman, J. D., Tedrow, L. M., \& Crowder, K. D. (2000). The changing demography of America's families. Journal of Marriage and the Family, 62(4), 1234-1246. doi: 10.1111/j.1741-3737.2000.01234.x 
Terhell, E. L., Broese van Groenou, M. I., \& van Tilburg, T. (2001). Verschillen in het steunnetwerk en de sociale participatie van gescheiden mannen en vrouwen. Sociale Wetenschappen, 44(2), 93-114.

Terhell, E. L., Broese van Groenou, M. I., \& van Tilburg, T. (2007). Network contact changes in early and later postseperation years. Social Networks, 29(1), 11-24. doi: 10.1016/j.socnet.2005.11.006

Tomassini, C., Kalogirou, S., Grundy, E., Fokkema, T., Martikainen, P., Broese van Groenou, M. I., \& Karisto, A. (2004). Contacts between elderly parents and their children in four European countries: current patterns and future prospects. European Journal of Ageing, 1(1), 54-63. doi: 10.1007/s10433-004-0003-4

Van Peer, C., \& Carrette, V. (2007). Van theoretische en empirische diversiteit naar een onderzoeksmodel. In C. Van Peer (Ed.), De impact van een (echt)scheiding op kinderen en ex-partners (pp. 13-35). Brussel: Studiedienst van de Vlaamse Regering.

Van Rossem, T. (2013), De impact van de echtscheiding van een volwassen kind op de contacten met de ouders. Vrije Universiteit Brussel, onuitgegeven masterproef.

Vanderleyden, L., \& Audenaert, V. (2004). Ouderen en hun sociale contacten. In T. Jacobs, L. Vanderleyden, \& L. Vanden Boer (Eds.),
Op latere leeftijd. De leefsituatie van 55plussers in Vlaanderen (pp. 205-223). Antwerpen: Garant.

Virpi, T., Doyle, M., \& O'Dwyer, C. (2011). "He really leant on me a lot": Parents' perspectives on the provision of support to divorced and separated adult children in Ireland. Journal of Family Issues, 32(12), 1622-1646. doi: $10.1177 / 0192513 \times 11412036$

Wijckmans, B., \& Van Bavel, J. (2013). Divorce and adult children's perceptions of family obligations. Journal of Comparative Family Studies, 44(3), 291-310.

Wijckmans, B., Jappens, M., \& Van Bavel, J. (2009). Echtscheiding en sociaal kapitaal in Vlaanderen. In J. Pickery (Ed.), Vlaanderen Gepeild! 2009 (pp. 298-333). Brussel: Studiedienst van de Vlaamse Regering.

Wijckmans, B., Jappens, M., \& Van Bavel, J. (2011). De uitwisseling van informele steun met vrienden en familie. In D. Mortelmans, I. Pasteels, P. Bracke, K. Matthijs, J. Van Bavel, \& C. Van Peer (Eds.), Scheiding in Vlaanderen (pp. 305-323). Leuven: Acco. 


\section{BiJLAGE}

Hieronder geven we een overzicht van de constructie en de bevraging van de gebruikte variabelen. We starten met de variabelen die betrekking hebben op de dataset van de volwassen kinderen, vervolgens geven we aan wat er verandert voor de dataset van de ouders. Er werd steeds gewerkt met de ongewogen data, vermits de wegingen nog niet beschikbaar waren op het moment dat de analyses werden uitgevoerd.

\section{Dataset van de volwassen kinderen}

Jaarlijkse contactfrequentie via ontmoetingen. Deze variabele is gebaseerd op de vraag die peilde naar de frequentie van dergelijk contact met de respectievelijke ouder per week, maand of jaar. Alle antwoorden zijn teruggebracht naar een frequentie per jaar. Door de methode van berekening is het maximum vastgelegd op 364. Dagelijks contact werd namelijk altijd per week gerapporteerd, en bij de berekening naar een jaarlijks aantal wordt dit: $7 * 52=364$. Bij het eerste overzicht van de afhankelijke variabelen, zijn de frequenties opgedeeld in de categorieën 'minstens 1 keer per week', 'minstens 1 keer per maand', 'minstens 1 keer per jaar' en 'nooit'.

Huwelijksstatus volwassen kind. Er wordt een onderscheid gemaakt tussen intacte referentiehuwelijken en feitelijk of wettelijk ontbonden referentiehuwelijken.

Huidig partnerstatuut volwassen kind. Deze variabele differentieert tussen personen wiens huwelijk nog intact is, gescheiden personen die niet samenleven met een nieuwe partner, en gescheiden personen waarbij er sprake is van een nieuwe partner in het huishouden.

Aanwezigheid kleinkinderen. We gebruiken een tot dummy gecodeerde variabele die weergeeft of er minstens één persoon jonger dan 12 jaar verblijft in het huishouden van de volwassen kinderen. Het kan daarbij gaan om een permanent of deeltijds verblijf van het kind in dit huishouden. De variabele differentieert ook niet tussen biologische kinderen, stiefkinderen, of andere jonge kinderen die in het huishouden verblijven.

Wekelijkse werkuren. De impact van het aantal werkuren wordt nagegaan aan de hand van een variabele die aangeeft of de respondent al dan niet een betaalde job heeft, met al dan niet normale werkuren. Vermits 38 uren per week op jaarbasis aanzien worden als een normale arbeidsregeling (FOD Werkgelegenheid, Arbeid en Sociaal Overleg, 2013), zijn diegenen die aangeven om gemiddeld meer dan 38 uren per week te besteden aan hun job (ook overuren en voorbereidend werk) ondergebracht in de categorie 'veel werkuren'.

Opleidingsniveau volwassen kind. Het opleidingsniveau werd van drieëntwintig categorieën herleid tot de volgende drie: laaggeschoolden (ten hoogste lager secundair onderwijs), middengeschoolden (ten hoogste hoger secundair of postsecundair onderwijs) en hooggeschoolden (hoger niet-universitair of universitair onderwijs).

Geografische afstand ten aanzien van de moeder/vader. Deze afstand wordt weergegeven aan de hand van het aantal minuten dat een persoon nodig heeft om van thuis het huis van de moeder/vader te bereiken. 
Aantal broers en zussen van volwassen kind. Door de vraagstelling betreft het niet enkel biologische broers en zussen, maar ook adoptiebroers of -zussen, stiefbroers of -zussen en halfbroers of -zussen.

Overige kenmerken volwassen kind. Tenslotte wordt er nog gecontroleerd voor het geslacht en de leeftijd (gecentreerd op 44 jaar) van het volwassen kind.

Kenmerken ouders (gerapporteerd door volwassen kind). Er wordt gecontroleerd voor de leeftijd van de ouders (gecentreerd op 71 jaar) en voor hun burgerlijke staat. Deze variabele maakt een onderscheid tussen gehuwden en verweduwde of gescheiden personen. In het geval van een scheiding houden we er tevens rekening mee of de andere ouder nog in leven was op het moment van de bevraging.

\section{Dataset van de ouders}

De meeste van de gebruikte variabelen blijven hetzelfde bij de analyses die uitgevoerd worden op de dataset van de ouders, en zijn dus ook bij die analyses gerapporteerd door de volwassen kinderen. De variabelen die wijzigen, en dus door de ouders gerapporteerd zijn, worden hieronder weergegeven.

Jaarlijkse contactfrequentie via ontmoetingen. De afhankelijke variabele is bij deze analyses door de ondervraagde ouder gerapporteerd. Belangrijk is om te vermelden dat de vraagstelling verschilt van de bevraging in de dataset van de volwassen kinderen. Aan de ouders werd immers gevraagd om met behulp van zeven verschillende categorieën aan te geven hoe vaak men het referentiekind ontmoet. Vermits we de contactfrequentie in de dataset van de volwassen kinderen op basis van de gestelde vraag konden herleiden tot een jaarlijks cijfer, hebben we gepoogd om dit eveneens bij deze dataset te doen. De verschillende categorieën werden daarom gelijkgesteld aan een zorgvuldig gekozen cijfer: dagelijks $=364$; verschillende keren per week (maar niet dagelijks) $=156 ; 1$ keer per week $=52$; verschillende keren per maand (maar niet wekelijks) $=26 ; 1$ keer per maand $=12$; minder dan 1 keer per maand $=6$; nooit $=0$.

Kenmerken ouders (gerapporteerd door ouders). Er wordt opnieuw gecontroleerd voor het geslacht van de ouders, hun leeftijd op het moment van de bevraging (gecentreerd op 71 jaar) en hun burgerlijke staat (gehuwd/verweduwd/gescheiden, andere ouder leeft/gescheiden, andere ouder gestorven). De variabelen zijn nu echter afgeleid van door de ouders gerapporteerde informatie. Er wordt bijkomend rekening gehouden met hun werkstatus (geen/wel betaalde job), hun opleidingsniveau (laaggeschoold/middengeschoold/hooggeschoold) en hun subjectieve gezondheidstoestand. Deze laatste variabele heeft betrekking op een vraag waarbij de ouders met behulp van vijf mogelijke antwoordcategorieën (zeer slecht/slecht/gaat wel/goed/zeer goed) hun algemene gezondheidssituatie dienden te beoordelen. Wij herleidden deze schaal tot een dummyvariabele die differentieert tussen een (zeer) goede gezondheid en een (zeer) slechte tot redelijke gezondheid. 
Tabel 3 Beschrijvende kenmerken van de gehanteerde variabelen

\begin{tabular}{|c|c|c|c|c|c|c|c|c|c|}
\hline & \multicolumn{3}{|c|}{$\begin{array}{l}\text { Dataset volwassen kinderen: } \\
\text { contact met moeder }(\mathrm{N}=4321)\end{array}$} & \multicolumn{3}{|c|}{$\begin{array}{l}\text { Dataset volwassen kinderen: } \\
\text { contact met vader }(\mathrm{N}=3215)\end{array}$} & \multicolumn{3}{|c|}{$\begin{array}{l}\text { Dataset ouders: } \\
\text { contact met volwassen kind }(\mathrm{N}=1667)\end{array}$} \\
\hline & Percentage & Gemiddelde (s.d.) & Min-max & Percentage & Gemiddelde (s.d.) & Min-max & Percentage & Gemiddelde (s.d.) & Min-max \\
\hline \multicolumn{10}{|l|}{ Kenmerken volwassen kind } \\
\hline Jaarlijkse ontmoetingen met ouder & & $104,31(106,82)$ & $0-364$ & & $98,21(105,70)$ & $0-364$ & & & \\
\hline Gescheiden (ref. gehuwd) & $72,5 \%$ & & & $71,0 \%$ & & & $65,6 \%$ & & \\
\hline \multicolumn{10}{|l|}{ Partnerstatuut (ref. gehuwd) } \\
\hline Ontbonden, zonder partner & $29,0 \%$ & & & $27,0 \%$ & & & $26,0 \%$ & & \\
\hline Ontbonden, met nieuwe partner & $43,5 \%$ & & & $44,0 \%$ & & & $39,6 \%$ & & \\
\hline Vrouw (ref. man) & $55,6 \%$ & & & $56,5 \%$ & & & $57,8 \%$ & & \\
\hline Kind(eren) in $\mathrm{HH}$ (ref. geen) & $38,6 \%$ & & & $43,2 \%$ & & & $45,1 \%$ & & \\
\hline $\begin{array}{l}\text { Leeftijd } \\
\text { (n) }\end{array}$ & & $44,91(7,56)$ & $23-68$ & & $43,64(7,35)$ & 23-65 & & $43,42(7,37)$ & $24-68$ \\
\hline $\begin{array}{l}\text { Job (ref. geen betaalde job) } \\
\text { Verminderde/normale werkuren }\end{array}$ & $38,7 \%$ & & & $39,6 \%$ & & & $39,8 \%$ & & \\
\hline Veel werkuren & $47,5 \%$ & & & $49,0 \%$ & & & $49,9 \%$ & & \\
\hline \multicolumn{10}{|l|}{ Opleidingsniveau (ref. laag) } \\
\hline Midden & $42,4 \%$ & & & $41,8 \%$ & & & $39,0 \%$ & & \\
\hline Hoog & $40,5 \%$ & & & $43,0 \%$ & & & $50,1 \%$ & & \\
\hline Afstand (minuten) & & $20,93(30,20)$ & $0-600$ & & $22,35(36,42)$ & $0-600$ & & $20,39(27,11)$ & $0-540$ \\
\hline Aantal broers/zussen & & $2,27(1,81)$ & $0-15$ & & $2,15(1,71)$ & $0-15$ & & $2,09(1,65)$ & $0-11$ \\
\hline \multicolumn{10}{|l|}{ Kenmerken ouders } \\
\hline $\begin{array}{l}\text { Jaarlijkse ontmoetingen met volwassen kind } \\
\text { Burgerlijke staat (ref. gehuwd met andere ouder) }\end{array}$ & & & & & & & & $102,58(99,66)$ & $0-364$ \\
\hline Verweduwd van andere ouder & $30,8 \%$ & & & $11,8 \%$ & & & $28,8 \%$ & & \\
\hline Gescheiden, andere ouder leeft & $8,4 \%$ & & & $10,1 \%$ & & & $5,9 \%$ & & \\
\hline Gescheiden, andere ouder gestorven & $3,9 \%$ & & & $1,3 \%$ & & & $2,9 \%$ & & \\
\hline Leeftijd & & $71,48(9,21)$ & 40-104 & & $71,78(8,80)$ & $44-99$ & & $70,69(8,73)$ & $47-94$ \\
\hline Vrouw (ref. man) & & & & & & & $63,7 \%$ & & \\
\hline $\begin{array}{l}\text { Betaalde job (ref. geen betaalde job) } \\
\text { Opleidingsniveau (ref }\end{array}$ & & & & & & & $8,7 \%$ & & \\
\hline $\begin{array}{l}\text { Opleidingsniveau (ref. laag) } \\
\text { Midden } \\
\text { Hoog }\end{array}$ & & & & & & & $\begin{array}{l}22,5 \% \\
14,5 \%\end{array}$ & & \\
\hline (Zeer) goede gezondheid (ref. (zeer) slecht tot redelijk) & & & & & & & $63,9 \%$ & & \\
\hline
\end{tabular}


2014, Vol 4 - Nr 3

\section{ENGLISH ABSTRACT}

Using data from the survey 'Divorce in Flanders', we study the relationship between the divorce of adult children and the frequency of face-to-face contacts with their parents. Doing so, we take into account contact frequencies reported by the adult children as well as frequencies reported by their parents. The results indicate that, when compared to married persons, divorced people have more face-to-face contact with both of their parents. More specifically, the frequency of encounters is the highest when one is not living with a new partner after the divorce. The differences according to the marital and partner status are significantly larger for sons than for daughters.

Keywords: Divorce, Flanders, intergenerational contact, adult children, parents 